\title{
MENGINTEGRASIKAN TEKNOLOGI INFORMASI DAN KOMUNIKASI (TIK) KE DALAM PROSES PEMBELAJARAN:
}

Apa, Mengapa dan Bagaimana?

\section{Abstrak}

Hidup dalam era informasi di abad 21 ini merupakan kenyataan. Teknologi informasi dan komunikasi (TIK) telah menjadi bagian yang tidak terpisahkan dari kehidupan era global saat ini. Untuk mendorong kesiapan SDM di era global melalui pendidikan di sekolah, pengintegrasian TIK ke dalam proses pembelajaran perlu dilakukan untuk 1) mengembangkan kemampuan berpikir tingkat tinggi siswa; 2) mengembangkan keterampilan dalam bidang teknologi informasi dan komunikasi (ICT literacy) itu sendiri; dan 3) untuk meningkatkan efektifitas, efisiensi dan kemenarikan proses pembelajaran. Dalam prakteknya, belum semua guru memahami apa yang dimaksud dengan mengintegrasikan TIK ke dalam proses pembelajaran. Makalah ini memaparkan tentang apa, mengapa dan bagaimana integrasi TIK dilakukan dalam proses pembelajaran di sekolah.

"In a global economy, it is education, not location, that determines the standard of living."

-Albert Hoser, CEO of Siemens- http://www.wtvi.com/teks/tia "Technology is a tool. A Means to end. Not the end in itself." http://www.wtvi.com/teks/integrate/tcea2001/ powerpointoutline.pdf

*) Uwes Anis Chaeruman, S.Pd., adalah Staff Sub Bidang Perancangan Sistem, Pustekkom, Depdiknas. 


\section{PENDAHULUAN}

Dunia telah berubah. Dewasa ini kita hidup dalam era informasi/global. Dalam era informasi, kecanggihan teknologi informasi dan komunikasi telah memungkinkan terjadinya pertukaran informasi yang cepat tanpa terhambat oleh batas ruang dan waktu (Dryden \& Voss, 1999). Berbeda dengan era agraris dan industri, kemajuan suatu bangsa dalam era informasi sangat tergantung pada kemampuan masyarakatnya dalam memanfaatkan pengetahuan untuk meningkatkan produktivitas. Karakteristik masyarakat seperti ini dikenal dengan istilah masyarakat berbasis pengetahuan (knowledge-based society). Siapa yang menguasai pengetahuan maka ia akan mampu bersaing dalam era global.

Oleh karena itu, setiap negara berlomba untuk mengintegrasikan Teknologi Informasi dan Komunikasi (TIK) untuk semua aspek kehidupan berbangsa dan bernegaranya untuk untuk membangun dan membudayakan masyarakat berbasis pengetahuan agar dapat bersaing dalam era global. Apa akibatnya? Negara yang telah maju dan mampu mengintegrasikan teknologi tersebut secara sistemik/holistik, melompat berkali lipat jauh lebih maju. Beberapa contoh yang telah maju dan jauh meninggalkan Indonesia di antaranya adalah Singapura, Jepang, dan Korea. Sementara itu, negara-negara berkembang lain yang belum mampu mengintegrasikan teknologi tersebut secara komprehensif semakin berkali lipat jauh tertinggal. Kondisi seperti ini dinamakan kesenjangan digital (digital divide).

Indonesia, perlu segera mengurangi kesenjangan digital ini dengan mengintegrasikan (TIK) secara sistemik untuk semua sektor pemerintahan seperti perdagangan/bisnis, administrasi publik, pertahanan dan keamanan, kesehatan dan termasuk pendidikan. Dalam makalah ini, penulis ingin mengupas masalah pengintegrasian TIK dalam pendidikan. Tapi, penulis membatasi pembahasan hanya pada masalah yang lebih mikro, yaitu pengintegrasian TIK dalam lingkup pembelajaran (ruang kelas). Sementara itu, yang dimaksud 
dengan teknologi informasi dan komunikasi di sini meliputi teknologi cetak maupun non-cetak (seperti teknologi audio, audio-visual, multimedia, internet, dan pembelajaran berbasis web).

Beberapa permasalahan yang penulis ingin coba dibahas dalam makalah ini meliputi: 1) apa yang dimaksud dengan pengintegrasian TIK ke dalam proses pembelajaran? 2) seperti apakah contoh bentuk pengintegrasian TIK ke dalam proses pembelajaran?; 3) mengapa TIK perlu diintegrasikan dalam pembelajaran?; 4) pendekatan seperti apa yang dapat digunakan dalam mengintegrasikan TIK ke dalam proses pembelajaran?; dan 5) pertimbangan apa sajakah yang perlu dilakukan dalam mengintegrasikan TIK ke dalam proses pembelajaran?

\section{Apa yang Dimaksud dengan Mengintegrasikan TIK ke dalam proses pembelajaran?}

Mari kita bandingkan dua kalimat berikut! "Learning to Use ICTS vs Using ICTs to Learn". Secara sederhana, mengintegrasikan TIK ke dalam proses pembelajaran sama maknanya dengan menggunakan TIK untuk belajar (using ICTs to learn) sebagai lawan dari belajar menggunakan TIK (learning to use ICTS). Belajar menggunakan TIK mengandung makna bahwa TIK masih dijadikan sebagai obyek belajar atau mata pelajaran.

Sebenarnya, UNESCO mengklasifikasikan tahap penggunaan TIK dalam pembelajaran kedalam empat tahap sebagai berikut:

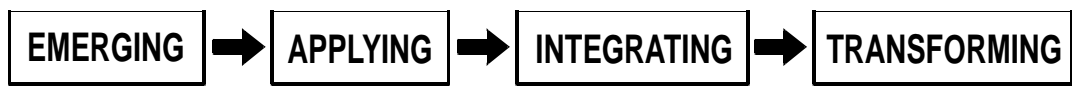

Tahap emerging, baru menyadari akan pentingnya TIK untuk pembelajaran dan belum berupaya untuk menerapkannya. Tahap applying, satu langkah lebih maju di mana TIK telah dijadikan sebagai obyek untuk dipelajari (mata pelajaran). Pada tahap integrating, TIK telah diintegrasikan ke dalam kurikulum (pembelajaran). Tahap transforming merupakan tahap yang paling ideal di mana TIK telah 
menjadi katalis bagi perubahan/evolusi pendidikan. TIK diaplikasikan secara penuh baik untuk proses pembelajaran (instructional purpose) maupun untuk administrasi (administrational purpose).

Apa yang terjadi dalam praktek pembelajaran di negara-negara berkembang, termasuk Indonesia, TIK masih dijadikan sebagai obyek atau mata pelajaran. Sebagian besar, TIK masih dijadikan sebagai obyek belajar atau mata pelajaran di sekolah-sekolah. Bahkan di tingkat perguruan tinggi atau akademi, banyak dibuka program studi yang berkaitan dengan TIK, seperti teknik informatika, manajemen informatika, teknik komputer, dan lain-lain.

Secara ideal, kondisi yang seharusnya terjadi adalah TIK sudah diintegrasikan dalam proses pembelajaran. Sebagai contoh, mari kita perhatikan salah satu bentuk pengintegrasian TIK ke dalam proses pembelajaran yang ditunjukkan dalam oleh suatu rencana pembelajaran (lesson plan) yang pernah dibuat oleh beberapa guru SMA sebagai berikut:

Tabel 1: Contoh Rencana Pembelajaran yang Mengintegrasikan TIK ${ }^{Y}$

Rencana pembelajaran di atas menunjukkan secara jelas bahwa melalui pengintegrasian TIK ke dalam proses pembelajaran, di samping tujuan pembelajaran tercapai, ada suatu agenda terselubung (hidden agenda) penting yang dapat dicapai pula, yaitu ICTs Literacy, seperti siswa dapat melakukan browsing informasi melalui internet, berkomunikasi melalui e-mail, membuat laporan dengan aplikasi pengolah kata (MSWord), atau mempresentasikan sesuatu dengan MSPowerpoint. Inilah yang dimaksud dengan mengintegrasikan TIK ke dalam proses pembelajaran. Fryer (2001) mengatakan bahwa penggunaan TIK dalam pembelajaran bertujuan untuk melatih keterampilan menggunakan TIK dengan cara mengintegrasikannya ke dalam aktifitas pembelajaran, bukan mengajarkan TIK tersebut sebagai mata pelajaran yang terpisah. Jadi, sudah saatnya TIK diintegrasikan ke dalam proses pembelajaran dan bukan hanya sekedar menjadi mata pelajaran yang terpisah. 


\begin{tabular}{|c|c|c|c|c|}
\hline No. & Topics & $\begin{array}{l}\text { Grade } \\
\text { Level }\end{array}$ & Objectives & Instructional Activities and ICT Used \\
\hline 1. & $\begin{array}{l}\text { The Creation of } \\
\text { Universe }\end{array}$ & $1^{\text {st }}$ & $\begin{array}{l}\text { Students will be able: } \\
\text { - to describe the } \\
\text { theories of } \\
\text { universe creation } \\
\text { - to compare } \\
\text { theories of } \\
\text { universe creation } \\
\text { among each } \\
\text { other }\end{array}$ & $\begin{array}{l}\text { - students watch video shows (VCD) } \\
\text { of the universe creation } \\
\text { - given a book of universe creation, } \\
\text { students (in group) analyze the } \\
\text { differences among theories of } \\
\text { universe creation } \\
\text { - each group write their report using } \\
\text { word processor application (e.g. } \\
\text { MS Word). } \\
\text { - each group present and discuss } \\
\text { their works in front of class. }\end{array}$ \\
\hline 2. & $\begin{array}{l}\text { Square } \\
\text { Equation }\end{array}$ & $1^{\text {st }}$ & $\begin{array}{l}\text { - to determine the } \\
\text { root of square } \\
\text { equation using } \\
\text { factor and abc' } \\
\text { formula (rules) } \\
\text { - to use } \\
\text { discriminant to } \\
\text { solve the square } \\
\text { equation problems }\end{array}$ & $\begin{array}{l}\text { - student studying the equation of } \\
\text { square from CD-ROM } \\
\text { - teacher discussing them and } \\
\text { explain how to use the rule of } \\
\text { square equation more deeply using } \\
\text { MS Powerpoint } \\
\text { - students solving problems given } \\
\text { by teacher } \\
\text { - as a follow up, students assign to } \\
\text { solve the problems related to the } \\
\text { square equation and write the } \\
\text { equation using equation facilities } \\
\text { on MS Word } \\
\text { - students submit their homework } \\
\text { via e-mail to the teacher }\end{array}$ \\
\hline 3. & $\begin{array}{l}\text { Narrative } \\
\text { Monolog } \\
\text { Discourse : } \\
\text { "Aspect of } \\
\text { Love" }\end{array}$ & $1^{\text {st }}$ & $\begin{array}{l}\text { to write a } \\
\text { monologue } \\
\text { discourses } \\
\text { related to the } \\
\text { theme of "Aspect } \\
\text { of Love" in the } \\
\text { form of poetry. }\end{array}$ & $\begin{array}{l}\text { - students choose a project related } \\
\text { to the theme of "Love" from } \\
\text { - students studying the project } \\
\text { description and procedures the } \\
\text { choosen } \\
\text { - students write their own poetry } \\
\text { related to the theme of "Love" } \\
\text { according to the project procedure } \\
\text { suggested using MS Word or MS } \\
\text { Power Point. } \\
\text { - Students send their poetry to the } \\
\text { teacher and their friends in the } \\
\text { world through mailing list (group) } \\
\text { on to have some comments or } \\
\text { feedback. }\end{array}$ \\
\hline
\end{tabular}

Y) Contoh ini diambil dari hasil Pelatihan Perancangan Pembelajaran Berbasis TIK yang dihasilkan oleh guru-guru SMA rintisan South-east Asia Schoolnet (SEASchoolnet) Program, kerjasama antara Pustekkom dengan UNESCO-Bangkok, 2004. Pelatihan ini juga dilaksanakan oleh delapan negara di Asia Tenggara yang tergabung dalam program tersebut. Sengaja dikutip sesuai aslinya dalam Bahasa Inggris. 


\section{Mengapa Pengintegrasian TIK ke dalam Proses Pembelajaran Penting?}

Jawabannya sangat berkaitan erat dengan mempersiapkan sumber daya manusia Indonesia untuk siap memasuki era masyarakat berbasis pengetahuan (knowledge-based society). Tahun 2020 Indonesia akan memasuki era perdagangan bebas (AFTA). Pada masa itu, masyarakat Indonesia harus memiliki ICT literacy yang mumpuni dan kemampuan menggunakannya untuk meningkatkan produktifitas (knowledge-based society).

Pengintegrasian TIK ke dalam proses pembelajaran dapat meningkatkan ICT literacy, membangun karakteristik masyarakat berbasis pengetahuan (knowledge-based society) pada diri siswa, di samping dapat meningkatkan efektifitas dan efisiensi proses pembelajaran itu sendiri.

UNESCO (2002) menyatakan bahwa pengintegrasian TIK ke dalam proses pembelajaran memiliki tiga tujuan utama, yaitu: (1) untuk membangun "knowledge-based society habits" seperti kemampuan memecahkan masalah (problem solving), kemampuan berkomunikasi, kemampuan mencari, mengoleh/mengelola informasi, mengubahnya menjadi pengetahuan baru dan mengkomunikasikannya kepada oranglain; (2) untuk mengembangkan keterampilan menggunakan TIK (ICT literacy); dan (3) untuk meningkatkan efektivitas dan efisiensi proses pembelajaran.

Mengapa demikian? Karena secara teoretis TIK memainkan peran yang sangat luar biasa untuk mendukung terjadinya proses belajar yang:

- Active; memungkinkan siswa dapat terlibat aktif oleh adanya proses belajar yang menarik dan bermakna.

- Constructive; memungkinkan siswa dapat menggabungkan ideide baru kedalam pengetahuan yang telah dimiliki sebelumnya untuk memahami makna atau keinginan tahuan dan keraguan yang selama ini ada dalam benaknya.

- Collaborative; memungkinkan siswa dalam suatu kelompok atau 
komunitas yang saling bekerjasama, berbagi ide, saran atau pengalaman, menasehati dan memberi masukan untuk sesama anggota kelompoknya.

- Intentional; memungkinkan siswa dapat secara aktif dan antusias berusaha untuk mencapai tujuan yang diinginkan.

- Conversational; memungkinkan proses belajar secara inherent merupakan suatu proses sosial dan dialogis dimana siswa memperoleh keuntungan dari proses komunikasi tersebut baik di dalam maupun luar sekolah.

- Contextualized; memungkinkan situasi belajar diarahkan pada proses belajar yang bermakna (real-world) melalui pendekatan "problem-based atau case-based learning"

- Reflective; memungkinkan siswa dapat menyadari apa yang telah ia pelajari serta merenungkan apa yang telah dipelajarinya sebagai bagian dari proses belajar itu sendiri. (Jonassen (1995), dikutip oleh Norton et al (2001)).

Dengan kata lain, TIK memungkinkan pembelajaran dapat disampaikan untuk berbagai modalitas belajar (multisensory), baik audio, visual, maupun kinestetik (dePorter et al, 2000). TIK memungkinkan pembelajaran disampaikan secara interaktif dan simulatif sehingga memungkinkan siswa belajar secara aktif. TIK juga memungkinkan untuk melatih kemampuan berpikir tingkat tinggi (seperti problem solving, pengambilan keputusan, dIl.) serta secara tidak langsung meningkatkan "ICT literacy" (Fryer, 2001).

Dari rencana pembelajaran di atas terlihat jelas bahwa melalui mata pelajaran Fisika, Biologi atau Bahasa Inggris misalnya, secara tidak langsung ICT literacy siswa berkembang. Di samping itu, dengan metode pembelajaran yang lebih bersifat konstruktif (contructivisme) secara tidak langsung keterampilan berpikir tingkat tinggi (seperti berpikir kritis, problem solving, dll.) dan keterampilan berkomunikasi dengan TIK pada 
diri siswa juga meningkat. Dengan kata lain, pengintegrasian TIK ke dalam proses pembelajaran dapat membangun karakteristik masyarakat berbasis pengetahuan (knowledge-based society) pada diri siswa. Jika pengintegrasian TIK ke dalam proses pembelajaran dilakukan sejak saat ini, maka siswa-siswi tahun 2005 misalnya, akan siap menjadi bagian dari masyarakat global pada masa diberlakukannya AFTA tahun 2020 mendatang. Penulis merasa bahwa pengintegrasian TIK ke dalam proses pembelajaran merupakan masalah yang "urgent" untuk mempersiapkan sumber daya manusia berbasis pengetahuan (knowledge-based human resources) yang sangat diperlukan di abad ke-21 ini.

Tidaklah heran kalau seorang futurolog, Eric Ashby (1972) seperti dikutip oleh Miarso (2004) menyatakan bahwa perkembangan TIK yang semakin mutakhir saat ini telah membawa revolusi pendidikan yang keempat. Revolusi pertama terjadi ketika orang menyerahkan pendidikan anaknya kepada seorang guru. Revolusi kedua terjadi ketika diguanakannya tulisan untuk keperluan pembelajaran. Revolusi ketiga terjadi seiring dengan ditemukannya mesin cetak sehingga materi pembelajaran dapat disajikan melalui media cetak. Revolusi keempat terjadi ketika digunakannya perangkat elektronik seperti radio, televisi komputer dan internet untuk pemerataan dan perluasan pendidikan.

\section{Bagaimana Mengintegrasikan TIK ke dalam Proses Pembelajaran?}

Dari sisi pendekatan, Fryer (2001) menyarankan dua pendekatan yang dapat dilakukan guru ketika merencanakan pembelajaran yang mengintegrasikan TIK, yaitu: 1) pendekatan topik (theme-centered approach); dan 2) pendekatan software (software-centered approach).

1 Pendekatan Topik (Theme-Centered Approach); Pada pendekatan ini, topik atau satuan pembelajaran dijadikan sebagai acuan. Secara sederhana langkah yang dilakukan adalah: 1) menentukan topik; 2) menentukan tujuan pembelajaran yang ingin dicapai; dan 3) menentukan aktifitas pembelajaran dan software (seperti modul. LKS, program audio, VCD/DVD, CD-ROM, bahan belajar on-line di internet, dII) yang relevan untuk mencapai tujuan pembelajaran 
tersebut. Rencana pembelajaran yang dicontohkan di atas merupakan salah satu contoh penggunaan pendekatan ini.

1 Pendekatan Software (Software-centered Approach); menganut langkah yang sebaliknya. Langkah pertama dimulai dengan mengidentifikasi software (seperti bku, modul, LKS, program audio, VCD/DVD, CD-ROM, bahan belajar on-line di internet, dII) yang ada atau dimiliki terlebih dahulu. Kemudian menyesuaikan dengan topik dan tujuan pembelajaran yang relevan dengan software yang ada tersebut. Sebagai contoh, karena di sekolah hanya ada beberapa VCD atau mungkin CD-ROM tertentu yang relevan untuk suatu topik tertentu, maka guru merencanakan pengintegrasian software tersebut untuk mengajar hanya topik tertentu tersebut. Topik yang lainnya terpaksa dilaksanakan dengan cara konvensional.

Sedangkan dari sisi strategi pembelajaran, ada beberapa pendekatan yang disarankan untuk membangun keterampilan berpikir tingkat tinggi siswa, diantaranya adalah: 1) resource-based learning; 2 ) case-based learning; 3) problem-based learning; 4) simulation-based learning; dan 5) collaborative-based learning (http://www.microlessons.com).

1 Resources-based learning memiliki karakteristik dimana siswa diberikan/disediakan berbagai ragam dan jenis bahan belajar baik cetak (buku, modul, LKS, dII) maupun non cetak (CD/DVD, CDROM, bahan belajar online) atau sumber belajar lain (orang, alat, dII) yang relevan untuk mencapai suatu tujuan pembelajaran yang ingin dicapai. Kemudain siswa diberikan tugas untuk melakukan aktifitas belajar tertentu dimana semua sumber belajar yang mereka butuhkan telah disediakan. Sebagai contoh, tujuan pembelajaran yang ingin dicapai adalah siswa dapat membandingkan beberapa teori penciptaan alam semesta. Untuk dapat mencapai tujuan pembelajaran tersebut, guru telah mengidentifikasi dan menyiapkan berbagai bentuk dan jenis sumber belajar yang berisi informasi tentang teori penciptaan alam semesta berupa buku, VCD, CD$\mathrm{ROM}$, alamat situs di internet dan mungkin seorang narasumber 
ahli astronomi yang diundang khusus ke kelas. Kemudian siswa ditugaskan untuk mencari minimal dua teori tentang penciptaan alam semesta secara individu atau kelompok baik dari buku, VCD, maupun internet sesuai dengan seleranya. Siswa juga diminta untuk menganalisis perbedaan dari berbagai segi tentang teori-teori tersebut dan membuat laporannya dalam MSWord yang kemudian dikirim ke guru dan teman lainnya melalui e-mail.

1 Case-based learning memiliki karakteristik dimana siswa diberikan suatu permasalahan terstruktur untuk dipecahkan. Dengan casebased learning solusi pemecahan masalahnya sudah tertentu karena skenario sudah dibuat dengan jelas. Tapi, dalam problembased learning kemungkinan solusi pemecahan masalahnya akan berbeda. Misal, dua orang siswa diberikan satu permasalahan dengan pendekatan problem-based learning. Maka solusi yang diberikan oleh siswa yang satu dengan siswa yang lain mungkin berbeda.

1 Simulation-based learning memiliki karakteristik dimana siswa diminta untuk mengalami suatu peristiwa yang sedang dipelajarinya. Sebagai contoh, siswa diharapkan dapat membedakan perubahan percampuran warna-warna dasar. Maka, melalui suatu software tertentu (misal virtual lab) siswa dapat melakukan berbagai percampuran warna dan melihat perubahanperubahannya. Dan ia dapat mencatat laporannya dalam bentuk tabel dengan menggunakan MSExcell atau MSWord. Atau kalau perlu mempresentasikan hasilnya dengan menggunakan MSPowerpoint.

1 Colaborative-based learning memiliki karakteristik dimana siswa dibagi kedalam beberapa kelompok, melakukan tugas yang berbeda untuk menghasilkan satu tujuan yang sama. Sebagai contoh, untuk mencapai tujuan pembelajaran dimana siswa dapat membedakan beberapa teori penciptaan alam semesta, siswa dibagi ke dalam tiga kelompok. Masing-masing kelompok ditugas kan mencari satu teori penciptaan alam semesta. Kemudian ketiga 
kelompok tersebut berkumpul kembali untuk mendiskusikan perbedaan teori tersebut dari berbagai segi dan membuat laporannya secara kolektif. Salah seorang siswa dapat ditunjuk untuk menyajikan hasilnya.

\section{Beberapa Pertimbangan yang Perlu Diperhatikan dalam Mengintegrasikan TIK ke dalam proses pembelajaran}

Ada beberapa hambatan yang perlu digaris bawahi berkaitan dengan pemanfaatan TIK untuk pembelajaran. Hambatan-hambatan tersebut diantaranya adalah: 1) penolakan/keengganan untuk berubah (resistancy to change) khususnya dari policy maker (kepala sekolah dan guru); 2) kesiapan SDM (ICT literacy dan kompetensi guru); 3) ketersedian fasilitas TIK; 4) ketersediaan bahan belajar berbasis aneka sumber; dan 5) keberlangsungan (sustainability) karena keterbatasan dana.

Penolakan atau keengganan untuk berubah, khususnya dari para pembuat kebijakan sekolah dan guru merupakan hal yang wajar mengingat TIK masih dapat dikatakan sebagai suatu inovasi (hal baru). Sikap para pengambil kebijakan atau guru terhadap TIK sebagian besar masih rendah disebabkan karena kurangnya pengetahuan terhadap TIK dan peran pentingnya bagi pembelajaran. Disamping itu, sikap keengganan/penolakan inipun didukung oleh karena redahnya melek teknologi (ICT literacy). Sehingga, kesiapan guru dan komptensi guru untuk memanfaatkan TIK dalam pembelajaran menjadi lemah. Walhasil, fasilitas TIK di sekolahpun menjadi terbatas sehingga keberlangsungan pemanfaatan TIK di sekolah juga masih dipertanyakan. Terlebih-lebih, ketersediaan bahan belajar berbasis aneka sumber (resources-based learning packages), seperti modul, buku paket, VCD pembelajaran, CD-ROM pembelajaran, maupun bahan belajar online masih terbatas.

Sebagai sumbang saran, dalam rangka mengintegrasikan TIK ke dalam proses pembelajaran (kelas), penulis merekomendasikan beberapa 


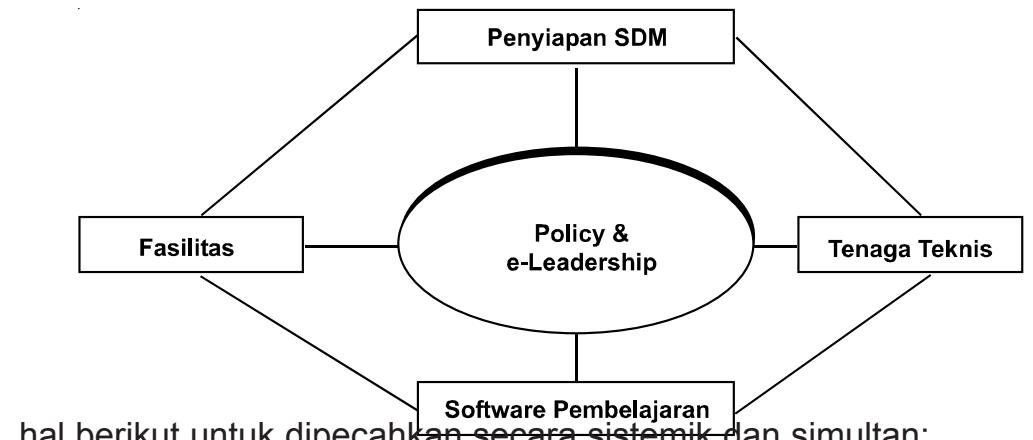

hal berikut untuk dipecahkan seeara sistemik dan simultan:

- Dukungan Kebijakan; sekolah mengeluarkan kebijakan untuk mengedepankan pengintegrasian TIK untuk pembelajaran. Misalnya melalui pencananagan visi, misi, peraturan dan rencana induk/rencana strategis sekolah ke depan.

- e-Leadership; Kepala sekolah dan atau beberapa guru panutan di sekolah menyadari penuh pentingnya peran TIK untuk pembelajaran dan berupaya untuk terus mempelajari dan menerapkannya di sekolah.

- Penyiapan SDM; sekolah mengembangkan ICT literacy para guru dan kompetensi guru dalam mengintegrasikan TIK kedalam pembelajaran (termasuk berbagai strategi/metode pembelajaran yang efektif). Bila perlu guru mengadopsi atau mengadaptasi strategi pembelajaran yang telah terbukti efektif dan mengkomunikasikannya dengan kolega. Bila perlu mengembangkan sendiri. Hal ini dpat dilakukan melalui pelatihan, pengiriman mengikuti loka karya atau seminar, terlibat aktif dalam komunitas jaringan sekolah dan lain-lain. Disamping itu, sekolah juga harus menyiapkan tenaga teknis dalam bidang TIK untuk 
pembelajaran.

- Penyiapan fasilitas; sekolah menyiapkan fasilitas yang kondusif agar terjadinya belajar berbasis aneka sumber dengan menyiapkan beberapa fasilitas seperti perpustakaan (cetak dan non-cetak), komputer yang terhubung dengan LAN, koneksi internet, VCD/DVD player plus televisi, serta komposisi ruang kelas.

- Penyediaan software pembelajaran; penyediaan software pembelajaran seperti buku, modul, LKS, program audio cassette, VCD/DVD, CD-ROM interaktif, dan lain-lain dapat dilakukan dengan cara membeli produk yang telah ada di pasar atau memproduksi sendiri.

- Penyiapan tenaga teknis; fasilitas TIK yang ada di sekolah hendaknya didukung oleh beberapa tenaga teknis yang memiliki keahlian atau keterampilan dalam mengelola dan memlihara peralatan tersebut.

\section{KESIMPULAN DAN HARAPAN}

Sebagai kesimpulan, akankah pengintegrasian TIK ke dalam proses pembelajaran dalam konteks kondisi Indonesia saat ini dapat berjalan dengan baik? Fakta nyata menunjukkan bahwa ada upaya secara sporadis dari beberapa sekolah-sekolah, baik sekoalh negeri maupun swasta di beberapa kota besar di Indonesia yang telah berupaya mengintegrasikan TIK ke dalam proses pembelajaran. Walaupun mungkin belum sempurna, tapi telah menunjukkan adanya perbedaan baik bagi hasil belajar maupun apresiasi siswa, orang tua maupun guru.

Contoh kecil tersebut, penting untuk dijadikan sebagai catatan. Ke depan, upaya beberapa sekolah yang secara sporadis ini perlu mendapat dukungan secara nasional sebagai bagian dari upaya peningkatan mutu pendidikan. Oleh sebab itu, pemerintah diharapkan dapat mengakomodasi masalah penting ini dengan secara top-down 
mengeluarkan suatu kebijakan pemanfaatan TIK untuk pendidikan (eeducation) yang disertai dengan dukungan infratsruktur teknologi informasi yang memadai. Akankah pendidikan Indonesia berjalan di tempat, sementara negara tetangga seperti Singapura, Malaysia, Fhilipina dan Thailand melesat jauh kedepan melalui visi e-educationnya yang jauh lebih terarah? MUDAH-MUDAHAN TIDAK!

\section{REFERENSI}

Dryden, Gordon; dan Voss, Jeanette; (1999), "the Learning Revolution: to Change the Way the World Learn", the Learning Web, Torrence, USA, http://www.thelearningweb.net.

Fryer, Wesley A.; (2001), "Strategy for effective Elementary Technology Integration", http://www.wtvi.com/teks/integrate/tcea2001/ powerpointoutline.pdf

NIE, Singapore, "General Typology of Teaching Strategies in Integrated Learning System", http://www.microlessons.com.

Norton, Priscilla; dan Spargue, Debra; (2001), "Technology for Teaching", Allyn and Bacon, Boston, USA.

UNESCO Institute for Information Technologies in Education (2002), "Toward Policies for Integrating ICTs into Education" Hig-Level Seminar for Decision Makers and Policy-Makers, Moscow 2002. Yusufhadi Miarso; (2004). "Menyemai Benih Teknologi Pendidikan" Prenada Media, Jakarta. 